\title{
Invasive rodents, an overlooked threat for skinks in a tropical island hotspot of biodiversity
}

\author{
Martin Thibault ${ }^{1,2 *}$, Fabrice Brescia ${ }^{2}$, Hervé Jourdan ${ }^{1}$ and Eric Vidal ${ }^{1}$ \\ ${ }^{1}$ Aix Marseille Univ, Univ Avignon, CNRS, IRD, IMBE, Centre IRD Nouméa - BP A5, 98848 Nouméa Cedex, New Caledonia \\ ${ }^{2}$ Institut Agronomique Néo-Calédonien (IAC), "Diversités biologique et fonctionnelle des écosystèmes terrestres", BP 73, \\ 98890 Païta, New Caledonia \\ *Author for correspondence: (Email: thibault@iac.nc)
}

Published online: 22 September 2016

\begin{abstract}
Squamata are one of the most threatened groups among island vertebrates, facing high pressure from exotic species. However, the contribution of small terrestrial reptiles in invasive rodents' diet remains poorly investigated, partly because of the lack of tools for accurately identifying chewed prey fragments in gut contents. The New Caledonia archipelago (South Pacific) hosts an exceptional terrestrial squamata fauna (105 species, 91.6\% endemic) that are faced with many invasive species (rodents, feral cats, feral pigs, ants) and strong human pressures. Our study aimed to evaluate the frequency of occurrence of endemic skink remains by gut content analysis of two species of invasive rodents. Four rodent trapping sessions were implemented at two ultramafic sites and for two distinct habitats (closed canopy forest and open shrubland habitat). A total of 284 rats were trapped from two species (the ship rat Rattus rattus and the Pacific rat $R$. exulans) over 1200 trap nights. Combined analysis of stomach and caecum contents provided far more information than traditional stomach analysis alone. Analyses showed that $15.9 \%$ of rat samples included remains of at least 12 different skink species out of the 23 present. Six species are classified as threatened by the IUCN, the most endangered being Marmorosphax taom (CR) and Kanakysaurus viviparus (EN). This study provides new prospects for the assessment of invasive rodent impacts and new insights into the respective impacts of two sympatric invasive rodent species on native skinks.
\end{abstract}

Keywords: diet analysis; endemic skinks; island conservation; Rattus exulans; Rattus rattus

\section{Introduction}

The main causes of biodiversity loss are now well identified: habitat fragmentation and destruction, invasive species and climate change (Sala et al. 2000; Pereira et al. 2012). Sax and Gaines (2008) and Tershy et al. (2015) have shown that, over the last 500 years, the majority of documented plant or vertebrate extinctions have occurred on islands. This pattern is especially true of extinctions caused by exotic species (Bellard et al. 2016). Walsh et al. (2012) showed that species richness and endemism increase the impact of exotic species on islands.

Rodents are among the most widespread commensal invasive species. They have been introduced to over $80 \%$ of the world's islands, with many harmful impacts (Atkinson 1985). We know that these opportunistic species are responsible for species depletion and/or extinction worldwide, especially in insular ecosystems (Courchamp et al. 2003; Harper \& Bunburry 2015). Invasive rodents can severely affect turtles and seabirds (Caut et al. 2008; Jones et al. 2008), amphibians (McCallum 1986) and mammals (Hanna \& Cardillo 2014; Smith \& Banks 2014). Several studies have shown that Rattus rattus is the most damaging rodent for island ecosystems (Jones et al. 2008; Ruffino et al. 2009; Traveset et al. 2009; Banks \& Hughes 2012; Shiels et al. 2014), and introduction of this species is followed by the greatest number of declines or extinctions of native island biota, according to Towns et al. (2006).

Case and Bolger (1991) revealed that island reptiles are highly threatened by introduced species, especially on islands that were predator-free before introductions. They found that rodents consume reptile eggs, young, and even adults, depending on prey size. These authors record several island reptile declines (lizards, tuatara) induced by the introduction of $R$. rattus, $R$. exulans or $R$. norvegicus. The blue-tailed skink (Cryptoblepharus egeriae) is assumed to have declined because of rodent predation on Christmas Island (Low et al. 2013), which is also the case for the endemic Belize leaf-toed gecko (Phyllodactylus insularis) on Half Moon Caye (Meerman 1996) and the whiptail lizard (Cnemidophorus vanzoi) on St Lucia (John 1999). On Rodrigues Island, large gecko species (Phelsuma edwardnewtoni and P. gigas) were devastated after rat introductions (Vinson \& Vinson 1969). The only two native lizards of Lord Howe Island (Phyllodactylus guentheri and Leiolopisma lichenigerum) are also known to have declined after the introduction of the black rat $R$. rattus in 1918 (Cogger 1971). Several New Zealand skink and gecko species are now confined to rat-free offshore islands, but bone deposits indicate that they were widespread on the mainland before rats were introduced (Worthy 1987). Furthermore, in New Zealand, skink and gecko species showed habitat plasticity after rat introduction (Whitaker 1978; Hoare et al. 2007) or removal (Towns 1991, 1996). More recently, Harper and Bunbury (2015) reviewed the impacts of invasive rats on islands, pointing out how herpetofauna features in the rodent diet. Even though island reptile records pre-dating rat introduction are often unavailable, the studies mentioned above, together with historical observations, point to rodents and other introduced species being important threats to the maintenance of island reptile communities over time. Tropical regions and oceanic islands have the highest proportion of threatened squamata species, according to Böhm et al. (2013). In particular, New 
Caledonia is considered by these authors as a world centre of threatened reptile species.

New Caledonia is one of the world's 35 biodiversity hotspots (Myers et al. 2000; Mittermeier et al. 2011). Located east of Australia in the Southwest Pacific, this tropical island hosts an outstanding squamata fauna, including 63 scincidae species (61 endemic), 36 diplodactylidae gecko (all endemic) and six geckonidae gecko species. This herpetofauna is of high biodiversity concern, given the exceptional endemism rates $(91.6 \%)$ and the unfavourable conservation status for most of the species, with 66 taxa considered as endangered (CR, EN or VU) (Whitaker \& Sadlier 2011; Bauer et al. 2012a, b; Sadlier et al. 2012, 2013, 2014a, b, c, d). This unique herpetofauna is facing high pressure from introduced alien species and human-induced habitat disturbances. Among invasives, four rodent species ( $R$. rattus, $R$. exulans, $R$. norvegicus and Mus musculus) introduced into New Caledonia may be responsible for a significant disruption of native herpetofauna (Beauvais et al. 2006). The Pacific rat ( $R$. exulans) was introduced into New Caledonia by Melanesian people between 2400 and 3300 years before present (Balouet 1984, 1987). The ship rat ( $R$. rattus), brown rat ( $R$. norvegicus) and house mouse $(M$. musculus) arrived more recently with European settlers around 1850 (Pascal et al. 2006). Rattus rattus and $R$. exulans are now widely distributed throughout the Caledonian archipelago (Rouys \& Theuerkauf 2003; Pascal et al. 2006) and are often sympatric, a situation widespread in Pacific islands but not known outside the region.

A better understanding of introduced rodent impacts on communities of squamata, especially in New Caledonia, as suggested by Bauer and Sadlier (2000), would appear to be vital to squamata conservation. In particular, the contribution of small terrestrial reptiles in invasive rodents' diet remains poorly investigated. The lack of experimental studies demonstrating rodent impacts and response to control methods contribute to explaining this lack of information.

The present study investigates the impacts of introduced rodents (ship rat and Pacific rat) on terrestrial reptiles. We explore a more efficient protocol of diet analysis to assess lizard consumption by rats, going beyond traditional analysis of stomach contents alone, as suggested in similar studies (Lewis et al. 2011). Using our own lab reference collection and an associated determination key of reptile remains, we evaluate reptile consumption occurrences. Finally, we considered management options in line with the conservation status of specific consumed species, from full removal to exclusion fencing.

\section{Materials and methods}

\section{Study sites}

Two distinct sites were selected for this study, both on ultramafic substrates (Fig. 1). On each site, rodents were sampled in two contrasting vegetation types: dense and open forest. The Goro site is located near Goro village, in the southern province of New Caledonia $\left(22^{\circ} 10^{\prime} 03^{\prime \prime} \mathrm{S} ; 166^{\circ} 55^{\prime} 36^{\prime \prime} \mathrm{E}\right)$. Fifteen skink (14 endemic) and 14 gecko (11 endemic) species are known to be present at this site (Table 1), of which seven and three species respectively are listed as threatened on the IUCN red list. The dense forest we selected is dominated by Arillastrum gummiferum, hosting $90 \%$ endemic plant species, with a canopy height of around $20 \mathrm{~m}$ (Jaffré et al. 2004). The open forest is dominated by Gymnostoma deplancheanum and Tristaniopsis spp., rising to a height of 6-10 metres (Jaffré et al. 2003).

The Tiebaghi site is in the northern province of New Caledonia $\left(20^{\circ} 33^{\prime} 43^{\prime \prime} \mathrm{S}, 164^{\circ} 15^{\prime} 43^{\prime \prime}\right.$ E) on Tiebaghi Mountain. Thirteen skink (all endemic) and eight gecko species (five endemic) are present, of which four and three species respectively are listed as threatened (Table 1). The dense forest is in a talweg and rises to a height of 20-25 m. The open forest habitat hosts few endemic arboreal species, with a canopy around $10 \mathrm{~m}$ and several endemic shrub species (Dagostini et al. 1997)

\section{Rodent trapping method}

As in Cunningham and Moors (1996), rodents were caught using lethal traps ('Trapper' snap traps for rats and 'E' mouse traps for mice, Pest Management Services, NZ). Trapping sessions involved 25 pairs of rat and mouse traps set at $25 \mathrm{~m}$ intervals along a $625 \mathrm{~m}$ transect in each of the habitats. The traps were baited with cheese (cheddar) and peanut butter. The mouse traps were placed under plastic tunnels to reduce the risk to non-target species.

We trapped rodents twice a year at each site in both forest types. Overall, four trapping sessions were conducted at each site and habitat. Trapping sessions in Goro were held in April and August 2013, and in January and March 2014. Trapping sessions in Tiebaghi were held in February, June and October 2013, and February 2014. Each trapping session lasted 4 days, i.e. 3 consecutive nights. Traps were baited just before nightfall and checked every morning. Following Cunningham and Moors (1996), each rat caught was weighed, sexed and measured for head-body length, tail length and reproductive status.

\section{Rodent diet analysis}

The digestive tracts of all the rodents caught were collected in the field, preserved in 70\% ethyl alcohol (Sugihara 1997) and frozen for further laboratory analysis. The contents were analysed according to the method described in Abbas (1988). Stomach and caecum were opened by incising the convex surface; the interior was scraped and the contents were poured into a $0.5 \mathrm{~mm}$ sieve. The contents were rinsed with tap water until the filtrate appeared clear, then placed in a Petri dish with

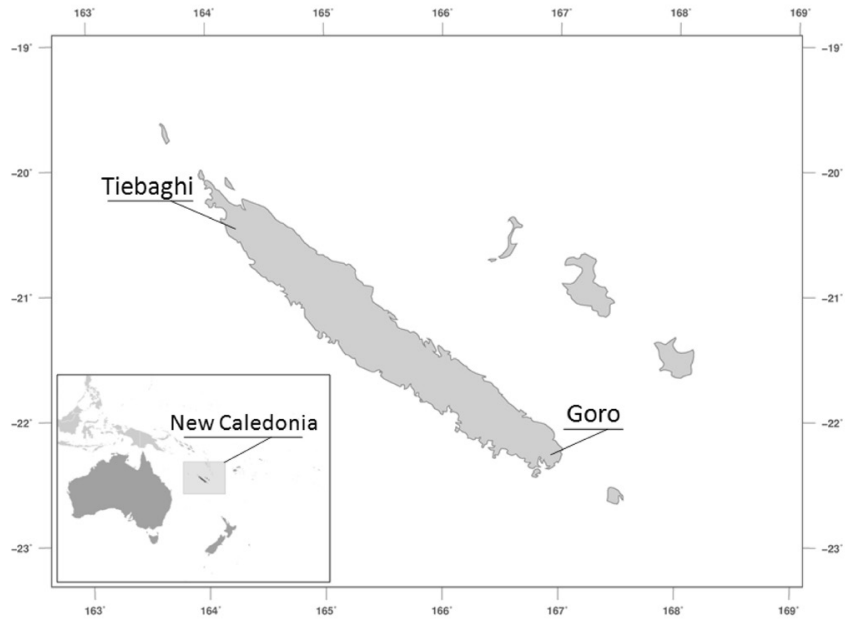

Figure 1. Location of New Caledonia and our two study sites on the New Caledonian mainland. 
Table 1. List of squamata recorded in each studied site. IUCN status according to Whitaker and Sadlier (2011); Bauer et al. (2012); Sadlier et al. (2013, 2014, 2015). Habitat: F: forest; MP: forested shrubland; M: Maquis shrubland. Status: E: endemic species; EE: endemic genera; A: native species; I=introduced species. Highlighted species were preyed-upon in this study.

\begin{tabular}{|c|c|c|c|c|c|c|}
\hline Scincidae & & Status & IUCN & Habitat & Tiéb. & Goro \\
\hline Caesoris novaecaledoniae & (Parker) 1926 & $\mathrm{EE}$ & $\mathrm{LC}$ & $\mathbf{M}$ & + & \\
\hline Caledoniscincus aquilonius & Sadlier, Bauer \& Colgan 1999 & E & NT & F, MP & + & \\
\hline Caledoniscincus atropunctatus & (Roux) 1913 & $\mathrm{~A}$ & $\mathrm{LC}$ & F, MP & + & \\
\hline Caledoniscincus auratus & Sadlier, Bauer \& Colgan 1999 & $\mathrm{E}$ & $\mathrm{EN}$ & F, MP & + & \\
\hline Caledoniscincus austrocaledonicus & (Bavay) 1869 & $\mathrm{E}$ & $\mathrm{LC}$ & F, MP & + & + \\
\hline Caledoniscincus festivus & (Roux) 1913 & $\mathrm{E}$ & $\mathrm{LC}$ & F, MP & + & + \\
\hline Caledoniscincus haplorhinus & (Günther) 1872 & $\mathrm{E}$ & $\mathrm{LC}$ & $\mathbf{M}$ & + & + \\
\hline Caledoniscincus notialis & Sadlier, Bauer, Wood, Smith \& Jackman 2013 & $\mathrm{E}$ & VU & F, MP & & + \\
\hline Caledoniscincus pelletieri & Sadlier, Whitaker, Wood \& Bauer 2014 & $\mathrm{E}$ & $\mathrm{CR}$ & F, MP & + & \\
\hline Cryptoblepharus novocaledonicus & (Mertens) 1928 & $\mathrm{E}$ & $\mathrm{LC}$ & M & & + \\
\hline Epibator nigrofasciolatus & (Peter) 1869 & $\mathrm{EE}$ & $\mathrm{LC}$ & F, MP, M & + & + \\
\hline Graciliscincus shonae & Sadlier 1986 & $\mathrm{EE}$ & VU & F, MP & & + \\
\hline Kanakysaurus viviparus & Sadlier, Smith, Bauer \& Whitaker 2004 & $\mathrm{EE}$ & EN & F, MP & + & \\
\hline Lacertoides pardalis & Sadlier, Shea \& Bauer 1997 & $\mathrm{EE}$ & VU & $\mathbf{M}$ & & + \\
\hline Marmorosphax taom & Sadlier, Smith, Bauer \& Whitaker 2009 & $\mathrm{EE}$ & $\mathrm{CR}$ & F, MP & + & \\
\hline Marmorosphax tricolor & (Bavay) 1869 & $\mathrm{EE}$ & $\mathrm{LC}$ & F, MP & & + \\
\hline Nannoscincus mariei & (Bavay) 1869 & $\mathrm{EE}$ & VU & $\mathbf{F}$ & & + \\
\hline Phasmasaurus tillieri & Ineich \& Sadlier 1991 & $\mathrm{EE}$ & NT & MP, M & & + \\
\hline Phoboscincus garnieri & (Bavay) 1869 & $\mathrm{EE}$ & $\mathrm{LC}$ & $\mathbf{F}, \mathbf{M P}$ & + & + \\
\hline Sigaloseps deplanchei & (Bavay) 1869 & $\mathrm{EE}$ & NT & F, MP & & + \\
\hline Simiscincus aurantiacus & Sadlier \& Bauer 1997 & $\mathrm{EE}$ & VU & F, MP & & + \\
\hline Tropidoscincus boreus & Sadlier \& Bauer 2000 & $\mathrm{EE}$ & LC & $\mathbf{M}, \mathbf{M P}, \mathbf{F}$ & + & \\
\hline \multirow[t]{2}{*}{ Tropidoscincus variabilis } & (Bavay) 1869 & $\mathrm{EE}$ & $\mathrm{LC}$ & MP, M & & + \\
\hline & & & & & 13 & 15 \\
\hline \multicolumn{7}{|l|}{ Diplodactylidae } \\
\hline Bavayia cyclura & (Günther) 1872 & $\mathrm{EE}$ & DD & $\mathbf{F}, \mathbf{M P}$ & & + \\
\hline Bavayia geitaina & Wright, Bauer \& Sadlier 2000 & $\mathrm{EE}$ & VU & F, MP & & + \\
\hline Bavayia goroensis & Bauer, Jackman, Sadlier, Shea \& Whitaker 2008 & $\mathrm{EE}$ & EN & $\mathbf{F}$ & & + \\
\hline Bavayia robusta & Wright, Bauer \& Sadlier 2000 & $\mathrm{EE}$ & $\mathrm{LC}$ & $\mathbf{F}$ & & + \\
\hline Bavayia sauvagii & (Boulenger) 1883 & $\mathrm{EE}$ & DD & F, MP & & + \\
\hline Bavayia septuiclavis & Sadlier 1989 & $\mathrm{EE}$ & NT & F, MP & & + \\
\hline Correlophus sarasinorum & (Roux) 1913 & $\mathrm{EE}$ & EN & $\mathbf{F}$ & & + \\
\hline Dierogecko nehoueensis & Bauer, Jackman, Sadlier, Whitaker 2006 & $\mathrm{EE}$ & $\mathrm{CR}$ & F, MP & + & \\
\hline Eurydactylodes agricolae & Henkel \& Böhme 2001 & $\mathrm{EE}$ & NT & $\mathbf{F}, \mathbf{M}, \mathbf{M P}$ & + & \\
\hline Eurydactylodes symmetricus & (Andersson) 1908 & $\mathrm{EE}$ & EN & F, MP & & + \\
\hline Eurydactylodes vieillardi & (Bavay) 1869 & $\mathrm{EE}$ & NT & F, MP & & + \\
\hline Mniarogekko jalu & Bauer, Whitaker, Sadlier \& Jackman 2012 & $\mathrm{EE}$ & EN & F, MP & + & \\
\hline Oedodera marmorata & Bauer, Jackman, Sadlier, Whitaker 2006 & $\mathrm{EE}$ & $\mathrm{CR}$ & $\mathbf{F}$ & + & \\
\hline Rhacodactylus auriculatus & (Bavay) 1869 & $\mathrm{EE}$ & $\mathrm{LC}$ & MP, M & + & + \\
\hline \multirow[t]{2}{*}{ Rhacodactylus leachianus } & (Cuvier) 1829 & $\mathrm{EE}$ & LC & F, MP & & + \\
\hline & & & & & 5 & 11 \\
\hline \multicolumn{7}{|l|}{ Gekkonidae } \\
\hline Hemidactylus frenatus & Schlegel in Duméril \& Bibron 1836 & I & $\mathrm{LC}$ & $\mathbf{M}$ & + & + \\
\hline Hemidactylus garnotii & Duméril \& Bibron 1836 & I & $\mathrm{LC}$ & $\mathbf{M}$ & + & + \\
\hline \multirow[t]{2}{*}{ Lepidodactylus lugubris } & (Duméril \& Bibron) 1836 & I & $\mathrm{LC}$ & $\mathbf{M}$ & + & + \\
\hline & & & & & 3 & 3 \\
\hline
\end{tabular}


$70 \%$ alcohol and examined under a dissecting microscope at $10 \mathrm{x}$ magnification.

We first analysed the entire digestive tracts of 20 individuals (five individuals of each sex per species) in order to determine which organs provided the most information on skink consumption. Four rats contained skink remains: three scales were found in small intestines, six in colons, 10 in stomachs and more than 60 in caecums. Each time we found scales in a gut, they were present in at least the stomach and the caecum. Therefore we focused our analysis on both stomach and caecum contents (separately) in order to maximize the probability of detecting reptile remains in the most time-efficient way.

Remains found in stomach and caecum were classified into nine categories: plants, insects, crustaceans, gastropods, earthworms, birds, parasites, geckos and skinks. Particular attention was given to the identification of skink remains up to species level, using our laboratory reference collection of skink scales. This collection consists of scales extracted from identified skinks and mounted for observation under microscope. We also used a skink scale determination key developed by our team during this project (Jourdan et al. 2014). Essentially, identifications were based on small groups of well-preserved scales sharing the same morphological patterns.

\section{Data analysis}

For each site, we calculated a relative abundance index based on the number of rats trapped during 100 trap nights, following the method described in Nelson and Clark (1973). All traps were checked every morning of each trapping session and the 'state' of the trap was recorded. If it was closed without a rat or still open without bait, the trap was considered as active for half a night only. The relative abundance index was then corrected by subtracting half a trap night for each of these traps.

For each item found during the diet analysis, we calculated an occurrence frequency by species and organ (stomach or caecum) as the number of individuals/organs containing the item divided by the total number of individuals analysed. We then related these frequencies to the skink conservation status, in order to determine those skink species potentially more sensitive to predation by introduced rodents.

We used the $\chi^{2}$ test of independence in $\mathrm{R}$ version 3.0.1 (R Development Core Team 2008) to determine whether skink remains occurrence frequencies differed between sites, habitats, rat species, sexes and maturity levels. When there were fewer than five samples, the Fisher exact test was used (Fisher \& Yates 1963).

\section{Results}

A total of 135 Pacific rats (R. exulans) and 50 ship rats $(R$. rattus) were captured during the four trapping sessions at the Goro site, while 35 individuals of $R$. exulans $(\mathrm{Re})$ and $63 R$. rattus $(\mathrm{Rr})$ were trapped at the Tiebaghi site (Table 2 ). The relative abundance index for Pacific rats was higher at Goro than at Tiebaghi $\left(\chi^{2}=12.7, d f=1, p=3.6 \times 10^{-4}\right)$, as shown in Figure 2. We recorded 24 Re. 100 trap night $^{-1}$ and 6 Re. 100 trap night $^{-1}$ at the two sites respectively. For ship rats, no significant difference was found between the two sites (11 Rr.100 trap night ${ }^{-1}$ in Goro; 12 Rr. 100 trap night $^{-1}$ in Tiebaghi). A total of 283 gut samples were taken for diet analysis (one rat was too damaged to be analysable). No mice were trapped at any site during this study.
Analysis of both stomachs and caecums led to significantly better detection of skink remains than did stomach analysis alone $\left(\chi^{2}=9.9 ; d f=1 ; p=0.0017\right)$. Combined analysis of these two digestive organs improved our detection capacity twofold compared with the 'classical' approach focused on the stomach alone (Fig. 3). Independent analyses of these two organs also suggest that caecums contained more skink remains than stomachs $\left(\chi^{2}=6.04 ; d f=1 ; p=0.014\right)$. Full results of the diet analysis are presented in Table 3. Plant items were present in $96.5 \%$ and $48.2 \%$ of ship rats and Pacific rats, respectively. Insects were found in inverse proportion: $93.5 \%$ in Pacific rats and $56.6 \%$ in ship rats. Feather remains were found in ship rats only $(\mathrm{n}=8)$, four cases at each site.

Squamata remains were found in $19.1 \%$ of analysed rats $(\mathrm{n}=283$, Table 3$)$. Of the rats, $15.9 \%$ had fed on skinks and $4.6 \%$ on geckos; $86 \%$ had consumed only one skink species, $13.9 \%$ had fed on two species. One Pacific rat contained remains of three species and one ship rat contained remains of seven skink species. No significant differences in skink predation by rats were found between the two sites $\left(\chi^{2}=0.02 ; d f=1 ; p=\right.$ $0.89)$, but skink consumption by the Pacific rat $(18.2 \% ; \mathrm{n}=170)$ was slightly more frequent compared with ship rat $(11.5 \%$; $\left.\mathrm{n}=113 ; \chi^{2}=2.72 ; d f=1 ; p=0.099\right)$. Rodents' maturity, sex and habitat did not significantly influence skink consumption rate (all analyses in Appendix S1 in Supplementary Material).

We were able to identify $91 \%$ of detected preyed skink individuals at species level. In this study, at least 12 skink

Table 2. Frequency of occurrence (in \%) of skink remains in the digestive tracts (both stomach and caecum) of ship rats ( $R$. rattus) and Pacific rats ( $R$. exulans). Percentages were calculated dividing the number of rat samples that contained skink remains by the corresponding sample size (n). Split percentages were rounded to one decimal place.

\begin{tabular}{llll}
\hline & Rattus exulans & Rattus rattus & Total \\
\hline Tiebaghi & $22.9 \%(\mathrm{n}=35)$ & $12.7 \%(\mathrm{n}=63)$ & $16.3 \%(\mathrm{n}=98)$ \\
Goro & $17.8 \%(\mathrm{n}=135)$ & $10 \%(\mathrm{n}=50)$ & $15.7 \%(\mathrm{n}=185)$ \\
Total & $18.8 \%(\mathrm{n}=170)$ & $11.5 \%(\mathrm{n}=113)$ & $\mathbf{1 5 . 9 \%}(\mathrm{n}=\mathbf{2 8 3})$ \\
\hline
\end{tabular}

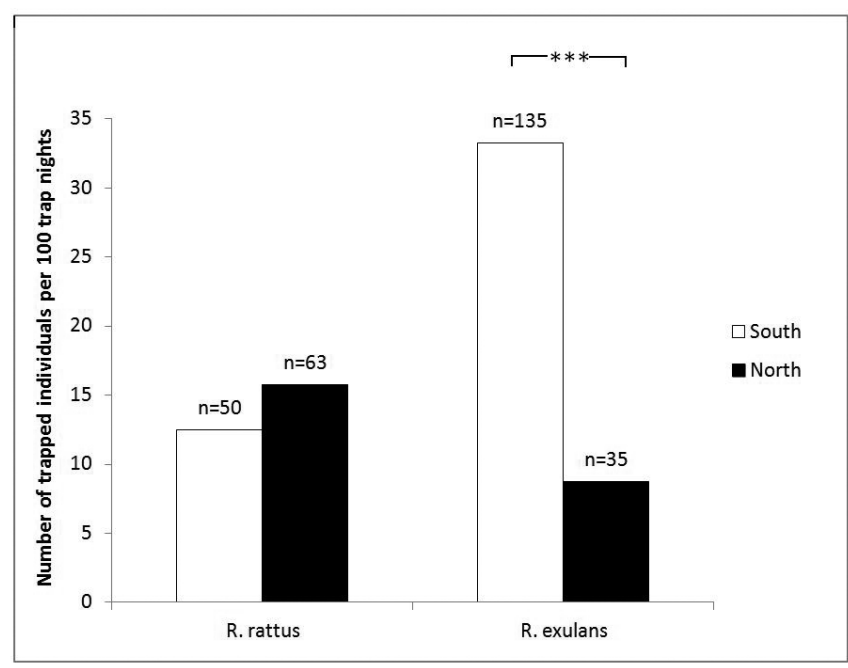

Figure 2. Results of trapping sessions, observed relative abundance indexes. $* * *: p<0.01$. 


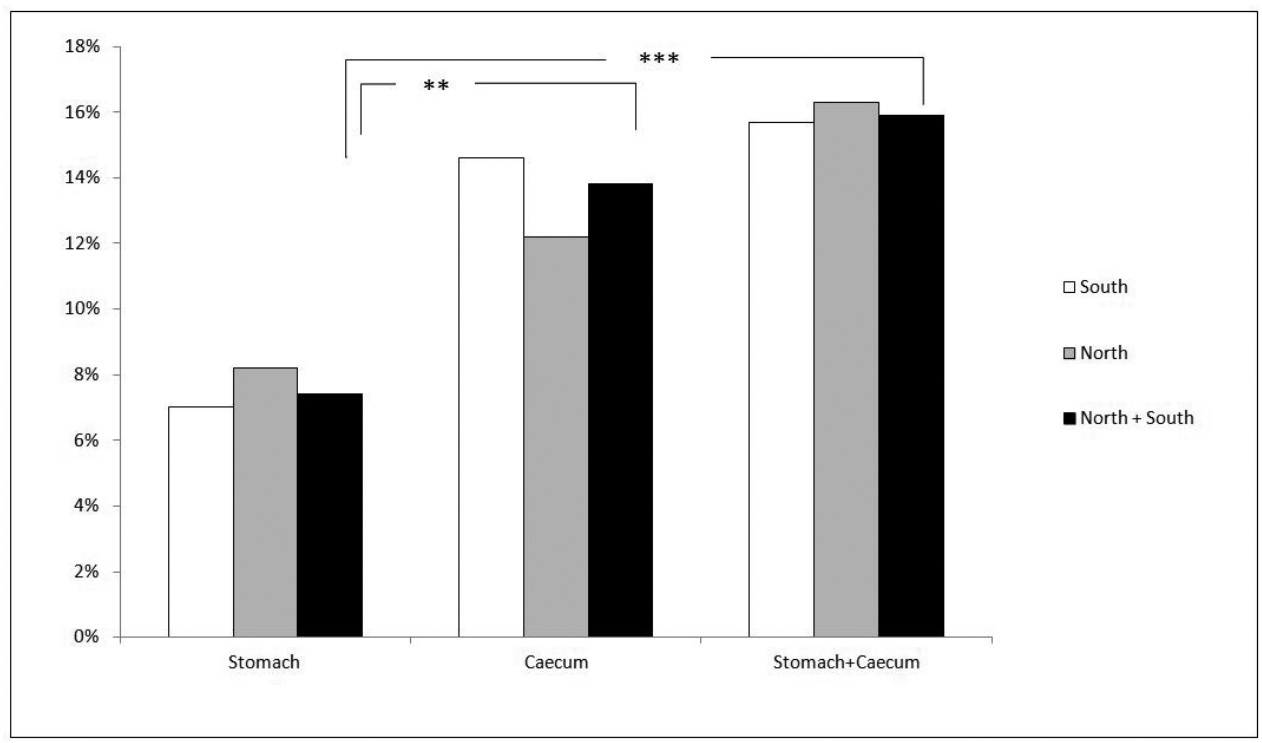

Figure 3. Frequency of occurrence of skink remains calculated for stomach and caecum contents analysed separately and together; $* *: 0.01<p<$ $0.05, * * *: p<0.01$.

Table 3. Percent frequency of occurrence of remains present in digestive tracts of ship rats $(R$. rattus $)$ and Pacific rats $(R$. exulans) on the two study sites. As some skink species were restricted to one of the two study sites, occurrences were corrected with the number of rodents trapped at the corresponding site. *Conservation status in UICN red list. Sample sizes in brackets.

\begin{tabular}{|c|c|c|c|c|c|}
\hline & & & \multicolumn{3}{|c|}{ Frequency of occurrence (no. ind.) } \\
\hline & & & R. rattus (113) & R. exulans (170) & Total (283) \\
\hline \multirow{2}{*}{\multicolumn{3}{|c|}{$\begin{array}{l}\text { Arthropods } \\
\text { Plants }\end{array}$}} & $56.6(64)$ & 93.5(159) & $78.8(223)$ \\
\hline & & & 96.5(109) & $48.2(82)$ & $67.5(191)$ \\
\hline \multirow{5}{*}{\multicolumn{3}{|c|}{$\begin{array}{l}\text { Crustaceans } \\
\text { Gastropods } \\
\text { Earthworms } \\
\text { Birds } \\
\text { Parasites }\end{array}$}} & $2.7(3)$ & $3.5(6)$ & $3.2(9)$ \\
\hline & & & $5.3(6)$ & $2.9(5)$ & $3.9(11)$ \\
\hline & & & $1.8(2)$ & $\mathbf{2 0 . 6}(35)$ & $13.1(37)$ \\
\hline & & & $7.1(8)$ & - & $2.8(8)$ \\
\hline & & & $77.0(87)$ & $65.3(111)$ & $70.0(198)$ \\
\hline \multirow{17}{*}{\multicolumn{2}{|c|}{$\begin{array}{cc}\text { Squamata } & \text { Geckos } \\
& \text { Skinks }\end{array}$}} & & $16.8(19)$ & $20.6(35)$ & 19.1(54) \\
\hline & & unidentified & $5.3(6)$ & $4.1(7)$ & $4.6(13)$ \\
\hline & & & $11.5(13)$ & $18.2(32)$ & $15.9(45)$ \\
\hline & & Caledoniscincus atropunctatus & $1.8(2)$ & - & $0.7(2)$ \\
\hline & & Caledoniscincus austrocaledonicus & $0.9(1)$ & $0.6(1)$ & $0.7(2)$ \\
\hline & & Caledoniscincus haplorhinus & - & $0.6(1)$ & $0.4(1)$ \\
\hline & & Caledoniscincus notialis & $0.9(1)$ & $0.6(1)$ & $0.7(2)$ \\
\hline & & Caledoniscincus sp. & $0.9(1)$ & $0.6(1)$ & $0.7(2)$ \\
\hline & & Graciliscincus shonae $(\mathrm{Vu})^{*}$ & $3.5(4)$ & 4.7(8) & $4.2(12)$ \\
\hline & & Kanakysaurus viviparus (En) & $3.5(4)$ & $3.5(6)$ & $3.5(10)$ \\
\hline & & Marmoroshpax taom $(\mathrm{Cr})$ & $0.9(1)$ & - & $0.4(1)$ \\
\hline & & Marmorosphax tricolor & $0.9(1)$ & $7.6(13)$ & $4.9(14)$ \\
\hline & & Nannoscincus mariei (Vu) & $0.9(1)$ & $1.2(2)$ & $1.1(3)$ \\
\hline & & Phasmosaurus tillieri & $0.9(1)$ & - & $0.4(1)$ \\
\hline & & Simiscincus aurantiacus (Vu) & $0.9(1)$ & $2.4(4)$ & $1.8(5)$ \\
\hline & & Tropidoscincus variabilis & $0.9(1)$ & - & $0.4(1)$ \\
\hline & & unidentified & $0.9(1)$ & $1.2(2)$ & $1.1(3)$ \\
\hline
\end{tabular}

species were found to be preyed upon by rats (Table 3). Of these skink species 11 are endemic to New Caledonia and six are considered threatened, according to the IUCN red list(Table 3). Of the skink species known to be present, $38.5 \%$ and $46.6 \%$ were consumed at Tiebaghi and Goro sites, respectively. It is noteworthy that Kanakysaurus viviparus (endangered) and Grasciliscincus shonae (vulnerable) are among the three most preyed-upon species by the two rat species. Our improved diet analysis method also revealed predation upon three other vulnerable species at Goro site (Caledoniscincus notialis, Simiscincus aurantiacus and Nannoscincus mariei), although they were not among the most frequently consumed species. The analyses of caecal contents also allowed us to detect the presence of scales from Marmorosphax taom (critically endangered) in one ship rat from the Tiebaghi site. 


\section{Discussion}

\section{Rodent diet analysis}

Analysis of caecal contents enabled us to determine rat diet over several food intakes more precisely than previous studies that focused on stomach analysis alone. Due to an estimated mean transit time of 12 hours in rats (Platel \& Crinivasan 2001), stomachs only contain remains from very few food intakes, whereas the caecum, as a digestive dead-end, accumulates remains from multiple food intakes, mainly remains difficult to digest, like fibres, cuticle fragments or scales. Combined analysis of stomach and caecum allowed us to improve our skink remains detection capacity twofold. Therefore we recommend including the analysis of this digestive organ in future rodent diet analysis.

We found no skink head bones or jaws in any rat digestive contents. This observation may indicate that rats do not eat skink heads, as other skeletal parts were found in some samples. It also confirms the importance of developing a morphological identification tool based on body scales instead of bones to measure skink predation by rodents. DNA-based methods of diet analysis are increasingly popular and may significantly improve prey detection and identification in the rodent diet (Egeter et al. 2015; Zarzoso-Lacoste et al. 2016). But such methods require access to prey DNA, which is not possible in our context because of the rarity and patrimonial status associated with most Caledonian skink species. However, we were able to identify about $91 \%$ of detected preyed skink individuals to species level due to morphological analysis of scales, as recommended in Fuchs and Fuchs (2003). This approach is already used to control the reptile skin trade (Fuchs \& Fuchs 2003) and we believe that the development of scale identification tools represents a major methodological improvement that will lead to better assessment of invasive rodent impacts on island endemic reptiles.

\section{Introduced rats' impact on native skinks}

Our results show frequencies of occurrence of skink remains of about $18.2 \%$ for $R$. exulans and $11.5 \%$ for $R$. rattus samples. These frequencies of occurrence are higher than most previously reported in the literature on island rats' diet. In their work on Surprise Islet, located northwest of New Caledonia, Caut et al. (2008) found remains of one skink species (C. haplorhinus; Bauer et al. 1992; Sadlier et al. 1999) in $13 \%$ of the digestive tracts (stomach and droppings) of ship rats they caught and analysed. In Tasmania, Norman (1970) found remains of skinks in a single ship rat's stomach out of the 254 samples analysed. In 1990, Newman and McFadden (1990) analysed the stomachs of 134 Pacific rats on offshore islands in New Zealand: only three of them contained skink remains. More recently in Hawaiian forests, a diet study on $R$. rattus, $R$. exulans and $M$. musculus conducted by Shiels et al. (2013) revealed the complete absence of any skink remains in the stomachs analysed ( $\mathrm{n}=12-95$ individuals per species). Our result can be explained by the high skink species richness and abundance in the archipelago (Bauer \& Sadlier 2000) combined with the likely improved estimation of predation rates in our study due to caecum content analysis.

For the two sites considered in this study, at least 12 different skink species among the 23 known to be present (c. $52 \%$ ) were identified in the gut contents of rats. Six of these prey species are under threatened conservation status according to the IUCN Red List criteria (Whitaker \& Sadlier 2011; Sadlier et al. 2013). Two worth mentioning are Marmorosphax taom and Kanakysaurus viviparus, endemic and restricted to a few mountains in the north of the mainland. In addition, four vulnerable species are consumed by rats. These observations, based on only two sites over small areas in New Caledonia, underline the importance of taking introduced rat predation into consideration in plans for the conservation of native skink communities on islands.

We found no remains of the arboreal skink species Epibator nigrofasciolatus (which is a very common species in every habitat in New Caledonia) in either ship or Pacific rats. Moreover, geckonid (arboreal) remains were found as frequently in Pacific rats $(n=7)$ as in ship rats $(n=6)$. This lack of arboreal prey species is unexpected, because the 'arboreal' lifestyle of $R$. rattus (Harper \& Bunbury 2015) could have been expected to lead to greater consumption of arboreal squamata prey by this species. Although the relative abundance of the two rodent species is not identical at our two study sites, their overall skink predation appears to be almost identical. We believe the small differences observed might be explained simply by the foraging behaviour of each rat species. The ship rat is arboreal with a diet mostly made of fruits and plant items (Shiels et al. 2014), on the other hand, the Pacific rat is a ground forager that consumes more invertebrates and fewer plants than the ship rat (Shiels et al. 2013). Our dietary analysis reveals the same pattern and accurately describes the differences in the diet of the two species; for example, feather remains were found in ship rats only, whereas earthworms were more abundant in Pacific rat guts.

We found slightly more squamata remains in $R$. exulans than in $R$. rattus in this study, as Pacific rats are smaller, ground foragers. However, more samples from other habitat types are needed to confirm this difference. Prey size does not seem to vary with the size of the rodent predator. The preyed-upon skinks in our study $(42-102 \mathrm{~mm})$ were in the middle of the size range of the species present at these sites $(25-200 \mathrm{~mm})$, and the biggest of these species was consumed equally by both rat species. The skink species most frequently consumed are nocturnal, which corresponds to the rodent activity period and could explain the high rates of occurrence of these species in rat diets. Prey species active at night could therefore be more sensitive to rat predation risk than diurnal species, as observed by Towns (1991).

Cumulative impacts have been suggested for sympatric introduced rodents (Montgomery et al. 2012). Here, our observations reveal that the rodent pressure is not homogeneous across the different skink species. We found Kanakysaurus viviparus and Graciliscincus shonae to be the most consumed skinks ( $\geq 6 \%$ of rats) globally and per rodent species, while the others skinks were found in less than $3 \%$ of rats. An associated study explored the abundance of each skink species at the two sites using sticky-trap grids (Jourdan et al. 2014). This study revealed that $K$. viviparus was the fourth most abundant species at Tiebaghi and G. shonae, a cryptic species living in the litter, has never been caught on sticky traps. This observation may indicate that some skink species are preferentially preyed upon by rodents. This pattern being shared by the two rodents means there could be a cumulative predation pressure upon some skink species. Unfortunately, two of the three most consumed species have threatened conservation status, which reinforces the stakes of this cumulative negative impact on skinks.

Our results confirm predation by introduced rodents to be a potentially important issue for skink conservation in New Caledonia, as some threatened species appear to be regularly 
preyed upon. However, this study examined only two sites in forests on ultramafic soil and it would be interesting to investigate introduced rodents' diet in other habitats like primary rainforest, dry forests, littoral habitats and some of the multiple islets surrounding New Caledonia. All these habitats are known to host endemic squamata, among the richest and most endemic of the archipelago's terrestrial fauna (Pascal et al. 2008). Moreover, the lack of ecological information on most of the New Caledonian skink species highlights the need to conduct research in order to better understand the pressures acting upon them. Particular attention needs to be paid to micro-endemic species (short range endemism) with unfavourable conservation status, especially because the three main types of pressures on biodiversity (Pereira et al. 2012) coexist in New Caledonia: (1) habitat destruction and fragmentation induced by mining activities, wildfires and urbanisation; (2) impact of multiple invasive species (rodents, feral cats, ants, etc.); and (3) effects of climate change. As elsewhere in the world, and particularly in tropical islands, addressing the second category of threats is perhaps the most feasible task in the short term. Control of new introductions is essential at points of entry (e.g. airports, harbours), but action can be taken against the species already present, especially in the areas most sensitive to biological invasions. According to Blackburn et al. (2011)'s proposals, rodent impacts could be addressed either by eradication or by mitigation. Rodent eradications have been implemented on several islands, sometimes leading to the recovery of seabirds, invertebrates, plants, forest birds and even lizards (Towns 1991; Smith et al. 2006; Towns et al. 2006; Le Corre et al. 2015; Jones et al. 2016). However rodent eradication appears to fail more often in tropical areas and eradications on human-inhabited islands remain a challenge (Russell \& Holmes 2015). Therefore, for the New Caledonian mainland (18 $\left.575 \mathrm{~km}^{2}\right)$, a complete removal is almost impossible given current rodent control methods. However, control and monitoring of rat populations at particularly sensitive sites can be implemented, so as to limit both population sizes and impacts (Q. Duron pers. comm.). At the Tiebaghi site for example, the rat impact upon $K$. viviparus $(\mathrm{En})$ and $M$. taom $(\mathrm{CR})$ is alarming and may warrant an urgent control program. According to Norbury et al. (2014)'s observations on native skink species recovery in New Zealand, exclusion fences were the most cost-effective option while considering small patches below 1 ha. Considering medium-sized patches from 1 to 219 ha, the same authors highlighted leaky fences as the 'best' solution, whereas lethal trapping appeared most efficient for areas larger than 219 ha, but recent control methods such as A24 self-resetting traps are promising for multi-species control on islands (Carter at al. 2016). As suggested in Doherty and Ritchie (2016), managers must consider the whole range of management approaches, methods, contexts and objectives in order to make control actions the most efficient. For example, in a tropical island hotspot of biodiversity threatened by mining activities, rodent control programs could also be implemented in a biodiversity offsetting perspective as suggested in Holmes et al. (2016). While the support of the population is absolutely essential in human-inhabited contexts (Glen et al. 2013), we believe that it is also fundamental to the conservation of native biodiversity on all islands. As underlined by Pascal et al. (2008), joint involvement is required in New Caledonia if we are to preserve a unique reptilian fauna from growing threats.

\section{Acknowledgments}

This study was part of the RMines project funded by 'CNRT Nickel et son environnement'. We express our gratitude to SLN and Vale mining companies for access to the study sites. We want to thank Ross Sadlier and the Australian Museum of Sydney for their help and access to the reptile collection. Thanks to Leo Debar and Helene De Meringo for their contribution to the analysis of scale morphology and to Frederic Rigault, Marc Manceau, Jean Claude Hurlin, Adrien Zubillaga, Wegune Wainebengo, Gilbert Shouene, Virginie Ujicas and Annie Portal for their help in the field. We finally thank Des Smith, Rod Hitchmough and one anonymous reviewer for their useful criticism and suggestions for improvement.

\section{References}

Abbas A 1988. Régime alimentaire d'un phytophage introduit, le ragondin (Myocastor coypus, Molina 1782) dans différents types de marais aménagés. Thèse Université Rennes I - Muséum National d'Histoire Naturelle. 200 p.

Atkinson IAE 1985. The spread of commensal species of Rattus to oceanic islands and their effects on island avifaunas. In: Moors PJ ed. Conservation of island birds. ICBPTechnical Publication 3. Pp. 35-81.

Balouet JC 1984. Paléontologie des vertébrés terrestres de Nouvelle-Calédonie et paléobiogéographie du Pacifique sud ouest. Unpublished Thèse de troisième cycle, Université Pierre et Marie Curie, Paris. 84 p.

Balouet JC 1987. Extinctions des vertébrés terrestres de Nouvelle-Calédonie. Mémoires de la Société Géologique de France 150: 177-183.

Banks PB, Hughes NK 2012. A review of the evidence for potential impacts of ship rats (Rattus rattus) on wildlife and humans in Australia. Wildlife Research 88: 39-78.

Bauer A, Renevier A, Sadlier R 1992. Caledoniscincus austrocaledonicus (Reptilia: Scincidae) from Ile Surprise, D'Entrecasteaux Reefs, New Caledonia. Pacific Science 46: 86-89.

Bauer AM, Sadlier RA 2000. The Herpetofauna of New Caledonia. Ithica, New York, Society for the Study of Amphibians and Reptiles in cooperation with the Institut de Recherche pour le Développement. 310 p.

Bauer AM, Jackma TT, Sadlier RA, Whitaker AH 2012a. Revision of the giant geckos of New Caledonia (Reptilia: Diplodactylidae: Rhacodactylus). Zootaxa 3404: 1-52.

Bauer AM, Sadlier RA, Jackman TT, Shea GM 2012b. A new member of the Bavayia cyclura species group (Reptilia: Squamata: Diplodactylidae) from the Southern ranges of New Caledonia. Pacific Science 66: 239-247.

Beauvais ML, Coléno A, Jourdan H 2006. Les espèces envahissantes dans l'archipel néo-calédonien: un risque environnemental et économique majeur. Paris, IRD Edition, Expertise collégiale. 262 p.

Bellard C, Cassey P, Blackburn TM 2016. Alien species as a driver of recent extinctions. Biology Letters 12:20150623.

Blackburn TM, Pyšek P, Bacher S, Carlton JT, Duncan RP, Jarošík V, Wilson JRU, Richardson DM 2011. A proposed unified framework for biological invasions. Trends in Ecology and Evolution 26: 333-339.

Böhm M, Collen B, Baillie JE, Bowles P, Chanson J, Cox N, Hammerson G, Hoffmann M, Livingstone SR, Ram M, Rhodin AGJ, Stuart SN, Dijk PP, Young BE, Afuang 
LE, Aghasyan A, García A, Aguilar C, Ajtic R, Akarsu F, Alencar LRV, Allison A, Ananjeva N, Anderson S, Andrén C, Ariano-Sánchez D, Arredondo JC, Mateo JA, Mathew R, Mathews N, Mayer G, McCranie JR, Measey GJ, Mendoza-Quijano F, Menegon M, Métrailler S, Milton DA, Montgomery C, Morato SAA, Mott T, MuñozAlonso A, Murphy J, Nguyen TQ, Nilson G, Nogueira C, Núñez H, Orlov N, Ota H, Ottenwalder J, Papenfuss T, Pasachnik S, Passos P, Pauwels OSG, Pérez-Buitrago N, Pérez-Mellado V, Pianka ER, Pleguezuelos J, Pollock C, Ponce-Campos P, Powell R, Pupin F, Díaz GEQ, Radder R, Ramer J, Rasmussen AR, Raxworthy C, Reynolds R, Richman N, Rico EL, Riservato E, Rivas G, da Rocha PLB, Rödel M-O, Schettino LR, Roosenburg WM, Ross JP, Sadek R 2013. The conservation status of the world's reptiles. Biological Conservation 157: 372-385.

Carter A, Barr S, Bond C, Paske G, Peters D, van Dam R 2016. Controlling sympatric pest mammal populations in New Zealand with self-resetting, toxicant-free traps: a promising tool for invasive species management. Biological Invasions 18: 1723-1736.

Case TJ, Bolger DT 1991. The role of introduced species in shaping the distribution and abundance of island reptiles. Evolutionary Ecology 5: 272-290.

Caut S, Angulo E, Courchamp F 2008. Dietary shift of an invasive predator: rats, seabirds and sea turtles. Journal of Applied Ecology 45: 428-437.

CoggerHG 1971. Thereptiles of Lord Howe Island. Proceedings of The Linnean Society of New South Wales 96: 23-8.

Courchamp F, Chapuis JL, Pascal M 2003. Mammal invaders on islands: impact, control and control impact. Biological Reviews 78: 347-383.

Cunningham DM, Moors PJ 1996. Guide to the identification and collection of New Zealand rodents. Wellington, Department of Conservation. $24 \mathrm{p}$.

Dagostini G, Veillon JM, Jaffré T 1997. Inventaire et caractérisation de la flore et des groupements végétaux du massif de la Tiébaghi. ORSTOM Sciences de la vie Botanique 9. 64 p.

Doherty TS, Ritchie EG 2016. Stop jumping the gun: a call for evidence-based invasive predator management. Conservation Letters. In press.

Egeter B, Bishop PJ, Robertson BC 2015. Detecting frogs as prey in the diets of introduced mammals: a comparison between morphological and DNA-based diet analyses. Molecular Ecology Resources 15: 306-316.

Fisher RA, Yates F 1963. Statistical tables for biological, agricultural and medical research. 6th edn. Edinburgh, Olivier \& Boyd. 155 p.

Fuchs K, Fuchs M 2003. The reptile skin: a key-feature in the identification of lizards and snakes. Frankfurt am Main, Edition Chimaira. 408 p.

Glen AS, Atkinson R, Campbell KJ, Hagen E, Holmes ND, Keitt BS, Parkes JP, Saunders A, Sawyer J, Torres H 2013. Eradicating multiple invasive species on inhabited islands: the next big step in island restoration? Biological Invasions 15: 2589-2603.

Hanna E, Cardillo M 2014. Island mammal extinctions are determined by interactive effects of life history, island biogeography and mesopredator suppression. Global Ecology and Biogeography 23: 395-404.

Harper GA, Bunbury N 2015. Invasive rats on tropical islands: their population biology and impacts on native species. Global Ecology and Conservation 3: 607-627.
Hoare JM, Pledger S, Nelson NJ, Daugherty CH 2007. Avoiding aliens: behavioural plasticity in habitat use enables large, nocturnal geckos to survive Pacific rat invasions. Biological Conservation 136: 510-519.

Holmes ND, Howald GR, Wegmann AS, Donlan CJ, Finkelstein M, KeittB 2016. The potential for biodiversity offsetting to fund invasive species eradications on islands. Conservation Biology 30: 425-427.

Jaffré T, Dagostini G, Rigault F, Coic N 2004. Inventaire floristique des unités de végétation de la zone d'implantation des infrastructures minières et industrielles de Goro Nickel. Rapport de synthèse IRD pour Goro Nickel SA. 69 p.

Jaffré T, Dagostini G, Rigault F 2003. Identification, typologie et cartographie des groupements végétaux de basse altitude du Grand Sud Calédonien et de la vallée de la Tontouta. ORSTOM Sciences de la vie - Botanique. 84 p.

John CL 1999. Population and habitat of the St Lucia Whiptail Lizard (Cnemidophorus vanzoi) on Praslin Island, St Lucia (West Indies). Report to St Lucia National Trust. 18 p.

Jones HP, Tershy BR, Zavaleta ES, Croll DA, Keitt BS, Finkelstein ME, Howald GR 2008. Severity of the effects of invasive rats on seabirds: a global review. Conservation Biology 22: 16-26.

Jones HP, Holmes ND, Butchart SH, Tershy BR, Kappes PJ, Corkery I, Aguirre-Muñoz A, Armstrong DP, Bonnaud E, Burbidge AA, Campbell K 2016. Invasive mammal eradication on islands results in substantial conservation gains. Proceedings of the National Academy of Sciences 113: 4033-4038.

Jourdan H, Brescia F, Vidal E 2014. Impact des espèces invasives sur les reptiles des massifs miniers. Rapport Scientifique CNRT/IRD/IAC. 91 p.

Le Corre M, Danckwerts DK, Ringler D, Bastien M, Orlowski S, Rubio CM, Micol T 2015. Seabird recovery and vegetation dynamics after Norway rat eradication at Tromelin Island, western Indian Ocean. Biological Conservation 185: 85-94.

Lewis DS, van Veen R, Wilson BS 2011. Conservation implications of small Indian mongoose (Herpestes auropunctatus) predation in a hotspot within a hotspot: the Hellshire Hills, Jamaica. Biological Invasions 13: 25-33.

Low BW, Mills H, Algar D, Hamilton N 2013. Home ranges of introduced rats on Christmas Island: a pilot study. Ecological Management \& Restoration 14: 41-46.

McCallum J 1986. Evidence of predation by kiore upon lizards from the Mokohinau Islands. New Zealand Journal of Ecology 9: 83-87.

Meerman KC 1996. HalfMoon Caye, Belize: terrestrial survey results and management implications. Report to Belize Audubon Society. 17 p.

Mittermeier RA, Turner WR, Larsen FW, Brooks TM, Gascon C 2011. Global biodiversity conservation: the critical role of hotspots. In: Zachos FE, Habel JC eds. Biodiversity hotspots. Springer Berlin Heidelberg. Pp. 3-22.

Montgomery WI, Lundy MG, Reid N 2012. 'Invasion meltdown': evidence for unexpected consequences and cumulative impacts of multispecies invasions. Biological Invasions 14: 1111-1125.

Myers N, Mittermeier RA, Mittermeier CG, Da Fonseca GA, Kent J 2000. Biodiversity hotspots for conservation priorities. Nature 403: 853-858.

Nelson L, Clark FW 1973. Correction for sprung traps in catch/effort calculations of trapping results. Journal of 
Mammalogy 54: 295-298.

Newman DG, McFadden I 1990. Seasonal fluctuations of numbers, breeding, and food of kiore (Rattus exulans) on Lady Alice Island (Hen and Chickens Group), with a consideration of kiore/tuatara (Sphenodon punctatus) relationships in New Zealand. New Zealand Journal of Zoology 17: 55-63.

Norbury G, Hutcheon A, Reardon J, Daigneault A 2014. Pest fencing or pest trapping: a bio-economic analysis of costeffectiveness. Austral Ecology 39: 795-807.

Norman FI 1970. Food preferences of an insular population of Rattus rattus. Journal of Zoology 162: 493-503.

Pascal M, Deforges B, Leguyader H, Simberloff D 2008. Mining and other threats to the New Caledonia biodiversity hotspot. Conservation Biology 22: 498-499.

Pascal M, Barré N, De Garine-Wichatitsky M, Lorvelec O, Frétey T, Brescia F, Jourdan H 2006. Les peuplements néo-calédoniens de vertébrés: invasions, disparitions. In: Beauvais ML, Coleno A, Jourdan H eds. Les espèces envahissantes dans l'archipel néo-calédonien: un risque environnemental et économique majeur. Paris, IRD Edition, Expertise collégiale. Pp. 116-162.

Pereira HM, Navarro LM, Martins IS 2012. Global biodiversity change: the bad, the good, and the unknown. Annual Review of Environment and Resources 37: 25-50.

Platel K, Srinivasan K 2001. Studies on the influence of dietary spices on food transit time in experimental rats. Nutrition Research 21: 1309-1314.

R Development Core Team 2008. R: a language and environment for statistical computing. Version 3.3.1. Vienna, Austria, R Foundation for Statistical Computing. www.R-project.org.

Rouys S, Theuerkauf J 2003. Factors determining the distribution of introduced mammals in nature reserves of the southern province, New Caledonia. Wildlife Research 30: 187-191.

Ruffino L, Bourgeois K, Vidal E, Duhem C, Paracuellos M, Escribano F, Sposimo P, Baccetti N, Pascal M, Oro D 2009. Invasive rats and seabirds after 2,000 years of an unwanted coexistence on Mediterranean islands. Biological Invasions 11: 1631-1651.

Russell JC, Holmes ND 2015. Tropical island conservation: rat eradication for species recovery. Biological Conservation 185: 1-7.

Sadlier RA, Bauer AM, Colgan DJ 1999. The scincid lizard genus Caledoniscincus (Reptilia: Scincidae) from New Caledonia in the southwest Pacific: a review of Caledoniscincus austrocaledonicus (Bavay) and description of six new species from Province Nord. Records of the Australian Museum 51: 57-82.

Sadlier RA, Whitaker T, Wood PL Jr, Bauer AM 2012. A new species of scincid lizard in the genus Caledoniscincus (Reptilia: Scincidae) from northwest New Caledonia. Zootaxa 3229: 47-57.

Sadlier RA, Bauer AM, Perry JL, Smith SA, Jackman TR 2013. Anew species of lizard in the genus Caledoniscincus (Reptilia: Scincidae) from southern New Caledonia and a review of Caledoniscincus atropunctatus (Roux). Zootaxa 3694: 501-524.

Sadlier RA, Bauer AM, Smith SA, Shea GM, Whitaker AH 2014a. High elevation endemism on New Caledonia's ultramafic peaks - a new genus and two new species of scincid lizard. In: Guilbert E, Robillard, T, Jourdan H, Grandcolas Peds. Zoologia Neocaledonica 8. Biodiversity studies in New Caledonia. Paris, Muséum National d'Histoire Naturelle. Pp. 115-125.

Sadlier RA, Bauer AM, Wood PL Jr, Smith SA, Whitaker AH, Jackman TR 2014b. Cryptic speciation in the New Caledonian lizard genus Nannoscincus (Reptilia: Scincidae) including the description of a new species and recognition of Nannoscincus fuscus (Günther). In: Guilbert E, Robillard, T, Jourdan H, Grandcolas P eds. Zoologia Neocaledonica 8. Biodiversity studies in New Caledonia. Paris, Muséum National d'Histoire Naturelle. Pp. 45-68.

Sadlier RA, Bauer AM, Wood PL Jr, Smith SA, Whitaker AH, Jourdan H, Jackman T 2014c. Localized endemism in the southern ultramafic bio-region of New Caledonia as evidenced by the lizards in the genus Sigaloseps (Reptilia: Scincidae), with descriptions of four new species. In: Guilbert E, Robillard T, Jourdan H, Grandcolas P eds. Neocaledonica 8. Biodiversity studies in New Caledonia. Paris, Muséum National d'Histoire Naturelle. Pp. 79-113.

Sadlier RA, WhitakerAH, Wood PL, Bauer AM 2014d. A new species of lizard in the genus Caledoniscincus (Reptilia: Scincidae) from far northwest New Caledonia. Zootaxa 3795: 45-60.

Sala OE, Chapin FS, Armesto JJ, Berlow E, Bloomfield J, Dirzo R, Wall DH 2000. Global biodiversity scenarios for the year 2100. Science 287: 1770-1774.

Sax DF, Gaines SD 2008. Species invasions and extinction: the future of native biodiversity on islands. Proceedings of the National Academy of Sciences USA 105: 11490-11497.

Shiels AB, Flores CA, Khamsing A, Krushelnycky PD, Mosher SM, Drake DR 2013. Dietary niche differentiation among three species of invasive rodents (Rattus rattus, $R$. exulans, Mus musculus). Biological Invasions 15: 1037-1048.

Shiels AB, Pitt WC, Sugihara RT, Witmer GW 2014. Biology and impacts of Pacific Island invasive species 11. Rattus rattus, the ship rat (Rodentia: Muridae). Pacific Science 68: 145-184.

Smith DG, Shiinoki EK, VanderWerf EA 2006. Recovery of native species following rat eradication on Mokoli' $i$ Island, O'ahu, Hawai'i. Pacific Science 60: 299-303.

Smith HM, Banks PB 2014. Disease and competition, not just predation, as drivers of impacts of the ship rat (Rattus rattus) on island mammals. Global Ecology and Biogeography 23: 1485-1488.

Sugihara RT 1997. Abundance and diets of rats in two native Hawaiian forests. Pacific Science 51: 189-198.

Tershy BR, Shen K, Newton KM, Holmes ND, Croll DA 2015. The importance of islands for the protection of biological and linguistic diversity. Bioscience 20: 1-6.

Towns DR 1991. Response of lizard assemblages in the Mercury Islands, New Zealand, to removal of an introduced rodent: the kiore (Rattus exulans). Journal of the Royal Society of New Zealand 21: 119-136.

Towns DR 1996. Changes in habitat use by lizards on a New Zealand island following removal of the introduced Pacific rat Rattus exulans. Pacific Conservation Biology 2: 286-292.

Towns DR, Atkinson IA, Daugherty $\mathrm{CH}$ 2006. Have the harmful effects of introduced rats on islands been exaggerated? Biological Invasions 8: 863-891.

Traveset A, Nogales M, Alcover JA, Delgado JD, LopezDarias M, Godoy D, Igual JM, Bover P 2009. A review of the effects of alien rodents in the Balearic (western Mediterranean Sea) and Canary Islands (eastern Atlantic Ocean). Biological Invasions 11: 1653-1670. 
Vinson J, Vinson JM 1969. The saurian fauna of the Mascarene Islands. The Mauritius Institute Bulletin 6: 203-320.

Walsh JC, Venter O, Watson JE, Fuller RA, Blackburn TM, Possingham HP 2012. Exotic species richness and native species endemism increase the impact of exotic species on islands. Global Ecology and Biogeography 21: 841-850.

Whitaker AH 1978. The effects of rodents on reptiles and amphibians. In: Atkinson IAE, Dingwall PR, Hay C eds. The ecology and control of rodents in New Zealand nature reserves. Information Series 4. Wellington, New Zealand Department of Lands and Survey. Pp. 75-88.

Editorial board member: Des Smith

Received 22 April 2016; accepted 25 July 2016

\section{Supplementary Material}

Additional supporting information may be found in the online version of this article:

Appendix S1. Results of Chi 2 and Fisher exact tests for skink predator individuals vs their attributes or the environmental context.

The New Zealand Journal of Ecology provides online supporting information supplied by the authors where this may assist readers. Such materials are peer-reviewed and copy-edited but any issues relating to this information (other than missing files) should be addressed to the authors.
Whitaker AH, Sadlier RA 2011. Skinks and geckos from New Caledonia. The IUCN Red List of Threatened Species. Version 2015-3. www.iucnredlist.org (accessed on 26 October 2015).

Worthy TH 1987. Osteological observations on the larger species of the skink Cyclodina and the subfossil occurrence of these and the gecko Hoplodactylus duvaucelii in the North Island, New Zealand. New Zealand Journal of Zoology 14: 219-229.

Zarzoso-Lacoste D, Bonnaud E, Corse E, Gilles A, Meglecz E, Costedoat C, Gouni A, Vidal E 2016. Improving morphological diet studies with molecular ecology: an application for invasive mammal predation on island birds. Biological Conservation 193: 134-142. 